\title{
Violations of Islamic Law in Male-Female Relations: The Shifting of Nyubuk Tradition of the Customary Peoples of Lampung
}

\author{
Suhairi ${ }^{*}$ \\ Siti Nurjanah ${ }^{2}$ \\ Saifuddin Zuhri Qudsy33 \\ Khoirul Abror ${ }^{4}$ \\ Mufliha Wijayati5 \\ Agus Alimuddin 6 \\ Ahmed Sarjoon Razick7 \\ Anas Tajudin 8

\begin{abstract}
1,2Department of Syari'ah Economy, Institut Agama Islam Negeri Metro Lampung, Jl. Ki Hajar Dewantara No.15A, Iringmulyo, Kota Metro, Lampung 34112, Indonesia 3 Faculty of Ushuluddin and Islamic Thought, Universitas Islam Negeri Sunan Kalijaga, Yogyakarta, Jl. Laksda Adisucipto, Caturtunggal, Kec. Depok, Kabupaten Sleman, Yogyakarta 55281, Indonesia ${ }^{4}$ Department of Syari'a Economy Law, Universitas Islam Negeri Raden Intan Bandar Lampung, Jl. Letnan Kolonel H Endro Suratmin, Sukarame, Kota Bandar Lampung, Lampung 35131, Indonesia 5 Department of Islamic Familiy Law, Institut Agama Islam Negeri Metro Lampung,Jl. Ki Hajar Dewantara No.15A, Iringmulyo, Kota Metro, Lampung 34112, Indonesia

${ }^{6}$ Department of Syari'a Economy, Institut Agama Islam Negeri Metro Lampung,Jl. Ki Hajar Dewantara No.15A, Iringmulyo, Kota Metro, Lampung 34112, Indonesia ${ }_{7}^{7}$ South Eastern University of Sri Lanka, $7 \mathrm{VW}_{2}+Q_{2} \mathrm{M}$, Oluvil, Sri Lanka ${ }^{8}$ University College of Islam Melaka, KM 25, 78200 Kuala Sungai Baru, Melaka, Malaysia *Corresponding Author
\end{abstract}

DOI: https://doi.org/10.36941/ajis-2022-0oo8

\section{Abstract}

Advances in media and communication technology have wrought significant shifts in the nyubuk tradition of the customary peoples of Lampung Pepadun. Male-female relations, once clearly regulated by customary doctrine through nyubuk, are now mediated by social media technology that facilitates the violation of customary and Islamic laws. This article examines how nyubuk, a cultural medium for communication that has traditionally been used in spouse selection, has shifted as social media has become widely available. More specifically, it seeks to understand how the nyubuk tradition has come to disappear without any significant resistance. In doing so, it applies a qualitative descriptive approach, with data having been collected through interviews. This study finds that despite generations of practice, shifting social and cultural practices have threatened nyubuk with extinction, and the practice has increasingly been replaced by social media. As a result, behaviors that violate social and religious norms have become increasingly common in society. Male-female relations, traditionally regulated under Islamic norms through nyubuk, have become increasingly open as cultural spaces have been replaced by social media. This has facilitated transgressions and other violations of Islamic law by young men and women. Obeisance of religious law depends significantly on local cultural authorities, and where these authorities are ignored, once dominant laws and practices may become extinct.

Keywords: legal violations, Islamic law, youth relationships, local tradition, social media 


\section{Introduction}

As information technology and media have become increasingly widespread, traditional mechanisms for regulating interpersonal relations have weakened. At the same time, this shift from cultural to internet-based communication media has transformed the norms and laws of society. For example, amongst the customary peoples (masyarakat adat) of Lampung Pepadun, the nyubuk tradition that has long shaped male-female interactions during spouse selection has been eroded by the widespread use of WhatsApp and other social media platforms. Interactions on these social media platforms have tended to violate the customary and Islamic laws observed in society. Campbell (2010) has argued that religious (and even customary) communities must continuously negotiate the changes wrought by new technologies to maintain their faith and their beliefs; among the people of Lampung, this negotiation has not occurred, and the nyubuk tradition has weakened.

Studies of the traditions of the customary peoples of Lampung have shown two tendencies. First, studies have tended to seek a broad-stroke portrait of local culture (Irianto \& Risma Margareta, 2011; Ningrum, 2017; Rosmana, 2010). As a result of ethnification, the customary peoples of Lampung have developed their local traditions and produced their understandings of pili pasegri (self-worth) to ensure their continued survival and to reposition their indigenous identities (Irianto \& Risma Margareta, 2011); Second, studies have positioned the negotiation and acculturation of Lampung culture vis-à-vis the religions practiced in Lampung (Humaedi, 2014; Isnaeni \& Hakiki, 2017; Nurdin, 2009). Particular focus has been given to the intersection between Lampung culture and Islam, which Isnaeni \& Hakiki (2017) liken to two sides of the same coin. Islamic law and local culture have become inexorably intertwined in Lampung, the result of successful assimilation. However, religious-cultural traditions have had difficulty enduring in the modern era. The erosion of nyubuk, a cultural communication medium traditionally used to regulate male-female interactions during spouse selection, is but one example; this blend of religion and culture, long ignored by scholars, has become less prevalent in the modern era.

This article seeks to investigate how nyubuk, a cultural medium for communication, has waned in the face of media technology. More specifically, it seeks to answer why the nyubuk tradition-a customary mechanism for mediating the communication between young men and women-has been allowed to fade without any significant resistance. This exploration of the nyubuk tradition and its potential extinction will also contribute to a broader understanding of the significant social transformations that have been instigated by the rise of internet technology.

This study departs from three arguments. First, it argues that the nyubuk tradition has faded as social differentiation has delegitimized communal cultural practices. Second, it argues that traditions cannot be maintained where high levels of social mobility exist, and thus traditions must be reoriented. Third, social differentiation and mobility have delegitimized cultural representatives, thereby resulting in the deauthorization of traditional leaders. Cultural and religious leaders are no longer viewed as representing the cultural order, and as such the cultural practices they advocate have been eroded.

As information and media technology has become increasingly widespread, the traditions that have regulated interpersonal relations and interactions have been eroded. This includes nyubuk, a cultural mechanism traditionally used to regulate male-female relations during spouse selection, which has been replaced by communication media in recent years. This shift has not only transformed male-female relations, but also the norms and laws of local society, violations of which have become increasingly common.

\section{Literature Review}

\subsection{Social Differentiation}

Social differentiation theory holds that individuals' diverse attitudes and behaviors can be attributed to their specific educational, economic, and cultural systems (Belhoste \& Monin, 2013). This theory 
provides an implicit definition of diversity, one rooted in disparity. Rehbein (2011) argues that social differentiation works through symbols, particularly language. All societies, all communities, and all cultures have their specific language or sociolect, having created specific linguistic systems as a means of distinguishing "us" from "them", "high" from "low", and incorporating this distinction within social functions, activities, and resources. Parsons, meanwhile, understands social differentiation as one of four modes of social evolution, all of which share one functional commonality: a social system (in Wortmann, 2012). Lenoir even argues that social spaces are "spaces of distinction", rather than realities in and of themselves; they are shaped by diverse hierarchies and dimensions (Valle \& Godoy, 2019).

Bases of social differentiation include (1) sex, (2) age, (3) race, (4) class, (5) sexual orientation, (6) disability, (7) religion, and (8) belief (Valentine \& Sadgrove, 2012). Individual actors' abilities, observation of cultural practices, and specific interests further influence their social differentiation (Schimank, 2015). In a study of Roman-era Britain, for instance, Cheung et al. (2012) found that social hierarchies were more distinct in urban settlements than in rural areas. Access to resources and goods, and even basic needs such as food, was determined by status within the hierarchy. Similarly, Ojong (2020) shows that hierarchies and social distinctions exist in various community events and rituals, where participants are differentiated based on their class, sex, heritage, property ownership, and indigeneity. Owing to their position in the hierarchy, some members of traditional communities may enjoy better socio-economic conditions than others. This does not determine social class but produces "complex hierarchal spaces" that may provide fertile ground for conflict (le Grand, 2019).

\subsection{Social Mobility: A Factor in Socio-Cultural Change}

The term 'social mobility' was first introduced in 1920, being used broadly by Sorokin to refer to the movement of individuals within social spaces. It is often used to refer to the movement of individuals within the social hierarchy, often as a result of individuals' efforts to increase their power, status, or prestige (Paisey, Paisey, Tarbert, \& $\mathrm{Wu}, 2020$ ). Mobility has been strongly influenced by industrialization and economic development; at the same time, however, it has been positively correlated with income gaps and immigration (Yaish \& Andersen, 2012). Blau argues that mobility subjects individuals to significant pressure, which may be manifested in instability in their habitusand, thus, suffering, discomfort, instability, and a sense of loss (Clark, Cummins, Hao, \& Vidal, 2015). Supporting this, Wang \& Gao (2013) cite an informant as stating that, based on the principle of social mobility, high-performing individuals must be stationed somewhere that acknowledges their value. "It is not that rural areas are best for us to recognize our value; we have no opportunity to improve ourselves."

Individual achievement and economic success may be realized through various instruments, from the meritocratic to the paternalistic (Gimpelson \& Monusova, 2014). Victoriano, Paez, \& Carrasco (2020) identify mobility strategies as consisting of four key dimensions: (1) time, (2) space, (3) money, and (4) social interactions. Melamed (2015) identifies several categories of mobility: social mobility, religious mobility, and educational mobility; all of these can be used to analyze the specific structures and patterns within society. Vielpeau, Lebel, Ardouin, Burdin, \& Lautridou (2011) show that individuals' experiences with mobility are shaped by both structural factors (for example, market conditions) and individual factors (for example, motivation). Faist (2013) identifies two types of mobility, horizontal and vertical; the former refers to the movement between different positions at the same level, while the latter refers to the movement between different levels of the social hierarchy. Faist (2013) adds that social mobility is one of the main measures of a society's modernity and evolution.

\subsection{Deauthorization of Leadership}

Leadership is a key determinant of success, be it within organizations, companies, communities, or 
nations. According to Seftyono et al. (2018), leadership is often equated with authority, and leaders tend to rely on their social capital to improve institutional relations and to facilitate the practice of power. Leaders' authority is dynamic, and where leaders are deauthorized their decisions are not obeyed or recognized (Koschmann et al., 2017). Deauthorization refers to the discursive practice in which the mechanisms used by traditional authorities to control their populations are undermined. As in developmentalist discourses, wherein customary peoples were branded primitive, local communities are systematically deprived of their rights (Wallerstein \& Duran, 2017). Deauthorization results in the degradation of leadership, as its traditional mechanisms (legitimacy, charisma, and trust) are replaced by rationalistic national ones. Even when leaders continue to receive noble titles and public support, their decisions lack binding power; they require both authority and legitimacy to maintain their customary role in local society and to uphold traditional beliefs (Mansur, Sofianto, \& Mahzuni, 2013).

According to Seftyono et al. (2018), local leadership requires several elements: 1) natural character; 2) group; (3) situation; (4) goals, and (5) interactions. At the same time, leadership cannot be achieved without authority and social support, both of which necessitate honesty, capability, and trust. Leaders cannot stand on their own, but require the authority derived from public support; alone, they lack resources, institutional access, and managerial capacity (Ellison \& Newmark, 2010). Even when local leaders do not present themselves as members of the dominant class, they nonetheless function to maintain and perpetuate their interests (Evans \& Sinclair, 2016). Nonetheless, Wallace \& Tomlinson (2010) write that local leaders have an important role in supporting local government, as they mediate communication between the populace and the highest echelons of society. Such leadership practices can experience significant changes. According to Lucky Zamzami (2013), using a case study of the Mentawai people, as the quality of life, education, and healthcare increases, and as consumption patterns and lifestyles transform, traditional barter systems and authorities are eroded.

\subsection{Compliance with Law}

The concept of compliance inexorably involves matters of conformity and adaptation (Thomann, 2015). It may be defined as the degree to which society obeys all applicable law, and thus as an indicator of the extent to which a law functions (Sari, Thalib, \& Junaidi, 2016). Compliance is often contrasted with incompliance, which fails to consider that different individuals may have different interpretations of law (Bondarouk \& Liefferink, 2017) and that these differences may influence how laws are implemented. Compliance with the law must be distinguished from mere awareness; in compliance, the law is obeyed for fear of potential sanctions (Rosana, 2014). The literature shows that society's perceptions of law enforcement are strongly correlated with compliance; for instance, Nagin \& Telep (2017) have shown that society's perceptions of the police influence the extent to which its members comply with the law. They thus recommend a procedural justice scheme, one in which dignity, belief, neutrality, and voice are built upon the foundation of fair treatment by impartial law enforcement. Such a scheme would create a perception of legitimacy, thereby promoting compliance.

The reverse is also true; compliance can increase perceived legitimacy.

However, Liao (2019) shows that compliance and legitimacy are conditioned by the cultural and social context in which the law is implemented. A study in China found that compliance has been supported by a cultural recognition of law and its values, rather than by mere matters of enforcement. According to Liao (2019), most studies of compliance have been conducted by psychologists in developed industrial nations. In recent years, there has been increased interest in the influence of technology on compliance (Barboza et al., 2014). There has also been the investigation of compliance within economic contexts, with a particular focus on corporations and their violations of applicable law (Nietsch, 2018; Salguero-Caparrós, Pardo-Ferreira, Martínez-Rojas, \& Rubio-Romero, 2020; Zinner, 2014); it has been argued that companies tend to have difficulty avoiding noncompliance and violation as legal obligations are deemed detrimental to companies' survivability 
(Salguero-Caparrós et al., 2020). In Indonesia, studies of compliance have often dealt with traffic, as well as the widespread violation of traffic laws (Agus, et al., 2016; Safitri \& Rahman, 2013).

\section{Method}

This article examines the tradition of nyubuk, as practiced amongst the customary peoples of Lampung Pepadun; this group, one of the two sub-ethnic groups of the Lampung people, has sought to maintain its traditions. Specific focus has been given to the Anak Tuha clan, who are distributed amongst eleven villages, or negara: Haji Pemanggilan, Bumi Libo, Bumi Aji, Aji Tuha, Bumi Udik, Aji Baru, Gunung Agung, Tanjung Harapan, Kuripan, Haduyang Ratu, and Padang Ratu. This clan was selected owing to its fervent dedication to maintaining tradition. Nonetheless, even amongst them, the practice of nyubuk is dying.

This article applies a qualitative descriptive approach to analyze primary and secondary data. Primary data were collected through in-depth interviews with members of the Adat Tuha clan, who were selected through purposive sampling, with the main criteria being the ability to shed light on the practice and its status within the customary community. Informants were as follows:

1. Semoga Jaya, a customary leader who has long been involved in traditional activities.

2. Komarul Zaman, a social and religious leader who married after practicing the nyubuk tradition

3. Dona Ismara, Tuwah Karya, Syukri, Zakaria, and Wijaya Putra, youths who married after practicing the nyubuk tradition

Data were collected through in-depth interviews with the above-mentioned informants. Interviews were used to collect data regarding the normative and practical elements of nyubuk, its waning, and the lack of effort to maintain it. Secondary data were collected through a review of the literature. Analysis was conducted through interpretation, concerning existing arguments, primary data, and expert opinion.

\section{Results}

\subsection{The Nyubuk Tradition: Normative and Ideal Conceptualization}

Traditionally, the practice of nyubuk among the Anak Tuha clan has resembled the practice among Lampung's other indigenous populations. Reflecting its etymology-the term nyubuk means 'to peek'-it is practiced furtively (Dona Ismara, February 1, 2020). This section will describe three aspects of nyubuk, as it has traditionally been conceptualized: the practice and time of nyubuk; the ethics and norms of nyubuk; and the further advancement of the relationship.

First, the practice and time of nyubuk. During the nyubuk tradition, a young man travels to the rear of a young woman's house. He may not take a direct path; instead, he must take an indirect route, potentially using alleys or neighbors' yards (interview with Syukri, Zakaria, Dona Ismara, February 1, 2020). This roundabout approach is intended to show the young man's respect for the young woman's father and brothers, as coming across them would be inappropriate or even unethical (Dona Ismara, February 1, 2020). Furthermore, during nyubuk, neither party may speak or laugh loudly. Nyubuk may only be conducted between 7:00 and 11:00 p.m.; any later, and the woman's mother or grandmother will give them a stern warning (Zakaria, February 1, 2020; Tuah, February 2, 2020).

Second, the ethics and norms for nyubuk. When a young man arrives at a young woman's house for nyubuk, he will give her a signal, either through ngetik (making a sound by tapping his thumb and middle finger together), lighting a match, or throwing a pebble. Upon receiving this signal, the young woman will enter the rear of the house and find a hole, through which she and her visitor can communicate (interview, Dona Ismara, Syukri, February 1, 2020). If they have never met, they will take turns showing each other their faces (Wijaya Putra, February 2, 2020). Throughout 
their discussion, the young man and woman will answer questions and learn more about others. One woman can draw the interest of multiple men; in such a situation, the men would take turns doing nyubuk, either in the order they arrived or based on previous agreement (Syukri, February 1, 2020, Wijaya Putra, Komarul Zaman, February 2, 2020).

Third, the further advancement of the relationship after nyubuk. Nyubuk is intended as a means for men and women to get to know each other; it is not binding or a formal relationship. Even when a young woman has entered a relationship, she is expected to provide other men with the opportunity for nyubuk (Syukri, February 1, 2020, Wijaya Putra, February 2, 2020). However, when she conveys that she has entered a serious relationship, her visitors will discontinue their nyubuk and their intentions. When a young man proposes marriage, and a young woman agrees, they will determine an appropriate time for larian/leaving for marriage (bebai). Where a young man is interested in a young woman who is already betrothed to someone else, he may 'kidnap' her through a practice known as nunggang (Komarul Zaman, February 2, 2020). Subsequently, discussions are held using traditional mechanisms, and the guilty party is expected to pay a customary fine.

As discussed above, the practice of nyubuk is a means through which young men and women can meet and interact. In this, it resembles the Islamic practice of taaruf. However, it is practiced following local socio-cultural practices and norms.

\subsection{Meeting Others through Social Media}

Although nyubuk has been practiced for generations, significant changes in society have resulted in it entering the threshold of extinction. Data show that the practice is waning amongst the people of Lampung. Three aspects of this will be discussed below: the loss of the nyubuk practice; the factors that threaten nyubuk with extinction, and the use of ngapel as a replacement.

First, the loss of the nyubuk practice. Today, the nyubuk tradition is no longer practiced by the young men and women of the Anak Tuha clan, having been pushed aside by technological advancements and developments. Putra explained that the practice had begun to disappear c. 2005 or 2006, as cellular phones and similar technologies became common (Wijaya Putra, February 2, 2020). According to Tuah, meanwhile, the practice had completely disappeared by 2003; he explained that, by the early 2000 , the practice had already waned, being practiced by only $15 \%$ of village youths $15 \%$ (Tuah, February 2, 2020).

Second, the factors threatening nyubuk with extinction. All informants stated that the practice of nyubuk began to fade after the introduction of cellular phones, as this technology facilitated both voice and short message service communication between young men and women (Semoga Jaya, Dona Ismara, Syukri, Zakaria, February 1, 2020; Wijaya Putra, Komarul Zaman, Tuah, February 2, 2020). At the same time, the nyubuk tradition was detrimentally affected by the mushrooming of transportation technologies (Tuah, February 2, 2020). Over time, nyubuk was replaced by short messages, telephone calls, and ready access to direct interactions in public spaces. Today, young men and women often meet in restaurants, shopping centers, cinemas, and other recreational spaces (Semoga Jaya, February 1, 2020; Wijaya Putra, Tuah, February 2, 2020). Social media platforms such as Facebook have penetrated rural areas in Lampung, including those occupied by the Anak Tuha clan, since 2010; before the advent of smartphones, these platforms were accessed through laptops and BlackBerry tablets.

Further accelerating the decline of nyubuk has been the increased prevalence of education. It is increasingly common for young men and women to live outside their hometowns, to study in the provincial capital of Bandar Lampung, or even in Java. Their interactions are mediated by Facebook and similar platforms, all of which include profiles that may be readily accessed. The use of WhatsApp has similarly transformed male-female interactions, as it has provided a medium through which young men and women can exchange photographs and videos, or even communicate directly through voice and video calls. Such interactions can easily be concealed from their parents (Tuwah, February 2, 2020). 
Third, ngapel as a replacement for nyubuk. Owing to the above factors, the nyubuk tradition has given way to a practice known as ngapel, wherein young men visit young women at their homes (Semoga Jaya, February 1, 2020; Wijaya Putra, Tuah, February 2, 2020). According to Tuah, the practice of ngapel was introduced by Lampung's sizable Javanese migrant community; the practice is not indigenous to Lampung (Tuah, February 2, 2020). Similarly, Wijaya Putra explained that the people of Lampung had not traditionally accepted guests at nighttime; 'open' visits were only conducted during daylight hours, while nyubuk was done furtively (Wijaya Putra, February 2, 2020). Tuwah distinguished between nyubuk and nemui, identifying the former as enabling young men and women to get to know each other, and the latter as occurring only once a relationship has been taken to a more serious level (Tuwah, February 2, 2020).

\subsection{Shifting Traditions and Violations of Customary Laws}

The erosion of the nyubuk tradition has had significant consequences for the people of Lampung. The following section will discuss three elements: the loss of nyubuk, the violation of the customary laws governing male-female interactions, and the negative social consequences of these phenomena.

First, the loss of the nyubuk tradition. This tradition contains within it many elements, including such values as discreteness (being conducted at the rear of the house, indirectly), mutual respect, soft-spokenness, and politeness as well as clear schedules and processes. These elements are recognized by young men and women, and all applicable guidelines are met with compliance (Dona Ismara, Syukri, Zakaria, February 1, 2020; Wijaya Putra, Tuwah, Komarul Zaman, February 2, 2020). These elements confirm with Islamic teachings; young men and women are prohibited from interacting directly, let alone touching each other, as they are separated by walls and other barriers (Zakaria, February 1, 2020; Komarul Zaman, February 2, 2020). As the nyubuk tradition has faded, having been replaced by communication technologies such as cellular phones and social media as well as direct interactions, so have its values (Syukri, Zakaria, February 1, 2020).

Second, the violation of the customary laws governing male-female interactions. As the nyubuk tradition has been replaced by cellular phones, social media, direct interactions, and ngapel, cultural values as shame, charity, and respect have been eroded; at the same time, vice, immorality, and other improprieties have become rampant. Unlike nyubuk, these new forms of male-female interactions are no longer monitored by parents (Tuwah, February 2, 2020). Young men and women communicate through cellular phones and social media, or meet outside the house, and thus have more opportunities to behave in ways that violate religious and cultural norms. As a result, premarital pregnancy rates have increased significantly (Syukri, Zakaria, February 1, 2020; Komarul Zaman, Tuwah, February 2, 2020).

Third, the negative social consequences of the loss of nyubuk. The erosion of the nyubuk tradition, as part of the general erosion of Lampung's customs and traditions, has also affected parents, traditional leaders. Although some social leaders have forbidden the practice of ngapel, deeming it as going against traditional values, their views have been ignored; rather, permissiveness has dominated. While serving as a youth leader, Wijaya sought to maintain the nyubuk tradition but was unsuccessful (Wijaya Putra, February 2, 2020). Tuwah stated that traditional leaders have made no serious efforts to uphold this tradition (Tuwah, February 2, 2020), and other informants agreed that traditional leaders have been unable to stem the flow of outside influences (Dona, Syukri, Zakaria, February 1, 2020). Consequently, immorality and impropriety have tainted male-female interactions.

\section{Discussion}

This study has shown that, over time, the nyubuk tradition has become threatened with extinction. This situation can be attributed to three major factors: increased differentiation within society; increased mobility without significant efforts to maintain tradition; and the weakening of local 
leaders.

First, increased differentiation within Lampung society. Over time, the Anak Tuha clan has begun abandoning its traditions and its customary values. Etiquette, politeness, ethical interactions, and compliance with applicable customary and religious laws are increasingly ignored. The loss of the nyubuk tradition the values it embodies, which have been swept away by advances in communication and transportation technology, has deleteriously affected how young men and women interact. There exists increased differentiation within customary society, with members of the Anak Tuha clan being increasingly set apart by their disparate educations and their economic and social statuses.

As stated by Behhoste and Monin (2013), such differentiation creates differences in individuals' attitudes and behaviors. Members of the society are understood as having a distinct social status, which implies different social functions and activities (Rehbein, 2011). According to Parsons (in Wortmann, 2012), social differentiation is one example of social evolution, one that is strongly influenced by functional considerations. These "spaces of distinction" create mutual dependence and hierarchies within diverse elements of society (Valle \& Godoy, 2019). This ultimately creates "complex hierarchal spaces" (Bourdieu, 1993). This holds amongst the members of the Anak Tuha clan as well; the new social hierarchy has resulted in individuals having different attitudes and interests, and this has hindered (potential) efforts to maintain traditions that are rooted in a spirit of communalism and shared interests. This can, as noted by le Grand (2019), provide fertile ground for conflict if left unchecked (le Grand, 2019).

Second, increased mobility without significant efforts to maintain tradition. All informants indicated that the nyubuk tradition waned as communication technology developed. These technologies enabled the young men and women of the Anak Tuha clan to communicate easily amongst them, as well as to arrange meetings elsewhere. As such, it cannot be denied that the decline of nyubuk was also precipitated by increased mobility. In other words, the nyubuk tradition has been eroded on two fronts: developments in communication technology, which facilitates direct communication between young men and women, and advances in transportation technology and infrastructure, which eases their efforts to meet outside the home. Such fronts might refer to the sotermed "phenomenon of encounter with the other" (Cami, 2013). Informants indicated that, because such direct meetings are significantly more enticing, it is not surprising that the nyubuk tradition is being abandoned.

Owing to increased ease of access to communication and information technology, as well as public transportation, the young men and women of the Anak Tuha clan have become more mobile. No longer are they limited to their villages; indeed, members of the Anak Tuha clan-particularly the youths-have become highly mobile. Many of them, after graduating from senior high school, travel elsewhere in search of employment or higher education; there are no universities or similar institutions in their customary territory. Such tendencies are widely reported in the literature (Yaish \& Andersen, 2012; Clark, Cummins, Hao, \& Vidal, 2015).

Third, the weakening of local/customary/cultural leaders. The nyubuk tradition is no longer prevalent amongst the members of the Anak Tuha clan, even though it conveys significant positive values; indeed, several informants stated explicitly that the tradition follows Islamic guidelines for interpersonal behavior; young men and women are prohibited from interacting directly or touching each other. Older members of the clan have expressed the desire for nyubuk to be maintained. However, these desires have directly conflicted with those of the younger generation. A small minority of parents has prohibited the practice of ngapel, instead insisting that their children only practice nyubuk; however, such prohibitions are not observed. Most informants stated that there have been no serious or concerted efforts to maintain the nyubuk tradition, and as a result, it has waned to the point that some youths are entirely ignorant of this tradition. Suhairi (2021) maintains that the traditional elders, Islamic religious leaders, and local government should play role in preserving Lampung tradition.

Customary leaders' inability to maintain such traditional practices as nyubuk indicates their lack of power within their communities. These leaders have experienced de-authorization as their 
communities have become more dynamic and differentiated. This supports previous findings, which have linked the de-authorization of traditional leaders with dynamicity (Koschmann et al., 2017), development (Wallerstein \& Duran, 2017), nationalist rationality (Mansur et al., 2013), and dependency (Ellison \& Newmark, 2010). Ultimately, as a result of this de-authorization, leaders have been unable to maintain their traditions. This is particularly tangible amongst the customary peoples of Lampung Pepadun, who are not united under the leadership of a single individual. In such a case, the local community should be the main stakeholder in maintaining cultural heritage (Saltman \& Abuamoud, 2020).

The nyubuk tradition, which is perceived as reflecting the values and laws of Islam, has been replaced by information and communication technology, wherein young men and women interact directly and thus have the opportunity to violate Islamic and cultural laws and doctrines. Islamic laws have been designed to ensure piety and advance the interests of the public; indeed, as nyubuk tradition (and, by implication, the Islamic teachings it represents) has been eroded, cases of immorality, rape, and premarital pregnancy have increased. Reflecting the arguments of Liao (2019), compliance with Islamic law has been conditioned by local society and culture; where these are undermined, rather than reaffirmed by strong leadership, the laws they have shaped are also threatened. It is worth noting that the sustainable implementation of Islamic values should be effective when it involves individual and collective efforts (Tahir, Rafiq, Yousufi, \& Sheikh, 2021).

\section{Conclusion}

Shifts in the nyubuk tradition, through which male-female relations have traditionally been regulated, have been precipitated in part by the expansion of information technology and social media. These changes, in turn, have significantly transformed cultural practices and facilitated the violation of Islamic and cultural laws that shape them. Male-female interactions are regulated through Islamic principles and norms, which are frequently violated when these interactions occur through communication media and technology. This has been a detrimental effect of the decline of the nyubuk tradition.

Through its use of theoretical concepts, this paper has applied a new and different perspective for understanding cultural transformations. The theoretical concepts used in this paper have facilitated its exploration of the nyubuk tradition and its implications for local culture and leadership. At the same time, these concepts have eased this study's exploration of the negative effects of cultural transformation: immorality, promiscuity, and extramarital pregnancy, all of which are firmly prohibited by Islam.

However, this study does have limitations. It has focused its discussion on the nyubuk tradition of Lampung's Anak Tuha clan. Numerous phenomena remain ripe for exploration, including the deauthorization of traditional leaders in Lampung and the assimilation of religious and cultural values within the province. Traditional leadership, which is legitimized by religious and cultural values, is a particularly interesting subject in the current social media era, on the one hand, as indicated in this paper, it has been deauthorized, while on the other hand, it has found new authority in its use of social media and other technologies to accumulate symbolic capital. This point, we argue, could be fruitfully explored in future studies.

\section{References}

Agus, A. A., Mustari, \& Umar, F. (2016). Analisis Tingkat Kepatuhan Hukum Berlalu Lintas Bagi Pengemudi Angkutan Umum Antar Kota Di Makasar. Jurnal Administrasi Publik, 6(2), $55^{-64 .}$ https://doi.org/10.26858/jiap.v6i2.2558

Belhoste, N., \& Monin, P. (2013). Constructing differences in a cross-cultural context: National distance, social differentiation or functional distinction. Human Relations. https://doi.org/10.1177/o018726713484943

Bondarouk, E., \& Liefferink, D. (2017). Diversity in sub-national EU implementation: the application of the EU Ambient Air Quality directive in 13 municipalities in the Netherlands. Journal of Environmental Policy and Planning. https://doi.org/10.108o/1523908X.2016.1267612 
Cami, E. (2013). Alterity Issues and the Roots of Western Views on Islam and Oriental Society. Academic Journal of Interdisciplinary Studies, 2(1), 473-476. https://doi.org/10.5901/ajis.2013.v2n1p473

Campbell, H. (2010). When Religion Meets New Media. In When Religion Meets New Media. https://doi.org/10.4324/9780203695371

Clark, G., Cummins, N., Hao, Y., \& Vidal, D. D. (2015). Surnames: A new source for the history of social mobility. Explorations in Economic History. https://doi.org/10.1016/j.eeh.2014.12.002

Da Silva Barboza, L., Gilberto, G. A., \& De Souza, R. A. C. (2014). Towards a legal compliance verification approach on the procurement process of IT solutions for the Brazilian Federal Public Administration. 2014 IEEE 7 th International Workshop on Requirements Engineering and Law, RELAW 2014 - Proceedings, 39-40. https://doi.org/10.1109/RELAW.2014.6893481

Ellison, B. A., \& Newmark, A. J. (2010). Building the reservoir to nowhere: The role of agencies in advocacy coalitions. Policy Studies Journal, 38(4), 653-678. https://doi.org/10.1111/j.1541-0072.2010.00378.x

Evans, M., \& Sinclair, A. (2016). Containing, contesting, creating spaces: leadership and cultural identity work among Australian Indigenous arts leaders. Leadership, 12(3), 270-292. https://doi.org/10.1177/1742715015620463

Faist, T. (2013). The mobility turn: A new paradigm for the social sciences? Ethnic and Racial Studies. https://doi.org/10.108o/o1419870.2013.812229

Humaedi, M. A. (2014). Kegagalan Akulturasi Budaya dan Isu Agama dalam Konflik Lampung. Analisa. https://doi.org/10.18784/analisa.v21io2.11

Irianto, S., \& Risma Margareta. (2011). Modal Budaya Dan Strategi Identitas Ulun Lampung Piil Pesenggiri : Cultural Capital and Identity Strategy of Ulun Lampung Abstract. Makara, Sosial Humaniora.

Isnaeni, A., \& Hakiki, K. M. (2017). Simbol Islam dan Adat dalam Perkawinan Adat Lampung Pepadun. KALAM. https://doi.org/10.24042/klm.v10i1.341

Koschmann, M., Kopczynski, J., Opdyke, A., \& Javernick-Will, A. (2017). Constructing Authority in Disaster Relief Coordination. 27, 1-24.

le Grand, E. (2019). Conceptualizing Social Types and Figures: From Social Forms to Classificatory Struggles. Cultural Sociology. https://doi.org/10.1177/1749975519859962

Lucky Zamzami. (2013). Sekerei Mentawai: Keseharian dan Tradisi Pengetahuan Lokal yang Digerus oleh Zaman Lucky. Indonesian Journal of Social and Cultural Anthropology, 34(1), 1-17.

Mansur, M., Sofianto, K., \& Mahzuni, D. (2013). Otoritas Dan Legitimasi Kedudukan Pemimpin Tradisional Di Loloda Maluku-Utara (1808-1958). Sosiohumaniora, 15(1), 64-72.

Martínez Valle, L., \& Martínez Godoy, D. (2019). Territorial dynamics and social differentiation among peasants in the northern highlands of Ecuador. Journal of Agrarian Change. https://doi.org/10.1111/joac.12322

Melamed, D. (2015). Communities of classes: A network approach to social mobility. Research in Social Stratification and Mobility. https://doi.org/10.1016/j.rssm.2015.05.001

Nietsch, M. (2018). Corporate illegal conduct and directors' liability: An approach to personal accountability for violations of corporate legal compliance. Journal of Corporate Law Studies, 18(1), $151-184$. https://doi.org/10.108o/14735970.2017.136546o

Ningrum, C. R. (2017). Fungsi Tari Nyambai Pada Upacara Perkawinan Adat Nayuh Pada Masyarakat Saibatin Di Pesisir Barat Lampung. Joged. https://doi.org/10.24821/joged.v10i2.1887

Nurdin, A. F. (2009). Integralisme Islam dan Nilai-nilai Filosofis Budaya Lokal pada Pembangunan Propinsi Lampung. Unisia. https://doi.org/10.20885/unisia.vol32.iss71.art6

Paisey, C., Paisey, N., Tarbert, H., \& Wu, B. (2020). Deprivation, social class, and social mobility at Big Four and non-Big Four firms. Accounting and Business Research. https://doi.org/10.108o/ooo14788.2019.1647127

Rehbein, B. (2011). Differentiation of sociocultures, classification, and the good life in Laos. Sojourn. https://doi.org/10.1355/sj26-2f

Rosana, E. (2014). Kepatuhan Hukum sebagai Wujud Kesadaran Hukum Masyarakat. Jurnal TAPIs, 10(1). https://doi.org/10.7551/mitpress/9894.003.0005

Rosmana, T. (2010). Mitos Dan Nilai Dalam Cerita Rakyat Masyarakat Lampung. Patanjala: Jurnal Penelitian Sejarah Dan Budaya. https://doi.org/10.30959/patanjala.v2i2.215

Safitri, A., \& Rahman, T. (2013). Tingkat Kepatuhan Hukum Siswa SMA Kartika IV-3 Surabaya terhadap Etika Berlalu Lintas Menurut Undang-undang Nomor 22 Tahun 2009 tentang Lalu Lintas dan Angkutan Jalan. Kajian Moral Dan Kewarganegaraan, 3(1), 485-499.

Salguero-Caparrós, F., Pardo-Ferreira, M. C., Martínez-Rojas, M., \& Rubio-Romero, J. C. (2020). Management of legal compliance in occupational health and safety. A literature review. Safety Science, 121, 111-118. https://doi.org/10.1016/j.ssci.2019.08.033 
Saltman, M., \& Abuamoud, I. (2020). The sustainable management of cultural heritage sites: Tourism and the politics of archaeology at petra. Academic Journal of Interdisciplinary Studies, 9(4), 46-54. https://doi.org/10.36941/AJIS-2020-006o

Sari, S. N., Thalib, S., \& Junaidi. (2016). Kepatuhan Hukum Masyarakat Nelayan Terhadap Larangan Penggunaan Alat Penangkapan Ikan Pukat Hela/Payang (Trawls) dan Pukat Tarik (Seine Nets) di Kota Padang. Prosiding SNaPP 2016 Sosial, Ekonomi, Dan Humaniora, 6(1), 316-323.

Seftyono, C., Luthfi, M., Rahayu, A. M., \& Alam, U. M. (2018). Accelerating Rural Development in Central Java Indonesia: Connecting Leadership, Social Capital and Policy in Local Context. IOP Conference Series: Earth and Environmental Science, 175(1). https://doi.org/10.1088/1755-1315/175/1/012185

Suhairi, S. (2021). The Impact of the Sesan Customary Practice on the Traditional Marriage of the Lampung Pepadun Society in Instilling Sharia Social Values Suhairi 1. Journal of Social Studies Education Research, $12(3), 225^{-247}$

Tahir, M., Rafiq, A., Yousufi, M., \& Sheikh, M. K. (2021). Eradicating gender-based violence against a femaleintimate partner in Pakistan: A theoretical framework from islamic philosophy. Academic Journal of Interdisciplinary Studies, 10(1), 340-356. https://doi.org/10.36941/ajis-2021-0029

Thomann, E. (2015). Customizing Europe: transposition as bottom-up implementation. Journal of European Public Policy. https://doi.org/10.1080/13501763.2015.1008554

Valentine, G., \& Sadgrove, J. (2012). Lived difference: A narrative account of spatiotemporal processes of social differentiation. Environment and Planning A. https://doi.org/10.1068/a44491

Victoriano, R., Paez, A., \& Carrasco, J. A. (2020). Time, space, money, and social interaction: Using machine learning to classify people's mobility strategies through four key dimensions. Travel Behaviour and Society. https://doi.org/10.1016/j.tbs.2020.02.004

Vielpeau, C., Lebel, B., Ardouin, L., Burdin, G., \& Lautridou, C. (2011). The dual mobility socket concept: Experience with 668 cases. International Orthopaedics. https://doi.org/10.1007/soo264-010-1156-8

Wallace, M., \& Tomlinson, M. (2010). Contextualizing leader dynamics: How public service leaders endeavour to build influence. Leadership, 6(1), 21-45. https://doi.org/10.1177/1742715009354238

Wallerstein, N., \& Duran, B. (2017). The Theoretical, Historical, and Practice Roots of CBPR. Community-Based Participatory Research for Health, 2(August 2016), 17-29. https://doi.org/10.1007/s13398-014-0173-7.2

Wang, D., \& Gao, M. (2013). Educational equality or social mobility: The value conflict between preservice teachers and the Free Teacher Education Program in China. Teaching and Teacher Education. https://doi.org/10.1016/j.tate.2013.01.008

Wortmann, H. (2012). A simple evolutionary model of social differentiation. Zeitschrift Fur Soziologie. https://doi.org/10.1515/zfsoz-2012-0504

Yaish, M., \& Andersen, R. (2012). Social mobility in 20 modern societies: The role of economic and political context. Social Science Research. https://doi.org/10.1016/j.ssresearch.2011.12.001

Zinner, S. (2014). Codes of ethics move into the "third generation." 2014 IEEE International Symposium on Ethics in Science, Technology and Engineering, ETHICS 2014, 5-7. https://doi.org/10.1109/ETHICS.2014.6893406 